is a difference of 10 per cent between the top and bottom of the tent with the greater concentration and killing at the bottom. At a temperature of $70^{\circ} \mathrm{F}$. there is better diffusion and a more even killing throughout the whole tent.

If there is no further discussion we shall pass on to the next paper which was to have been presented by Dr. H. P. Severin of the University of California. As he could not be present I am going to ask $\mathrm{Mr}$. C. F. Stahl, of the Bureau of Entomology, U. S. Department of Agriculture, who is at present time located in Riverside studying the sugar beet leafhopper, and who has been doing considerable work on this insect for several years to read the paper which is entitled "Notes on the Behavior of the Beet Leafhopper."

Mr. C. F. STahl: Dr. Severin has prepared two very interesting papers on the beet leafhopper, both of which throw new light upon this insect. The title of the first paper has already been announced and the subject matter follows:

\title{
NOTES ON THE BEHAVIOR OF THE BEET LEAFHOPPER (EUTETTIX TENELLA BAKER)
}

By Henry H. P. Severix, Ph.D., California Agricultural Experiment Station

\section{Sexuar Behavior}

Dr. E. D. Ball ${ }^{1}$ noticed a swarming of the beet leafhopper (Eutettix tenella Baker) "near Pauguitch, Utah, at an elevation of 7,000 feet, just at the time the immense swarms swept over the beet regions of Utah in 1915. They were first observed in the evening just as the sun was setting and at this time were flying around and hovering over a little patch of young pigweed"; this was interpreted as an evening rest while migrating. "The next morning they were there in numbers, but quite sluggish with the cold. When this patch was visited a little later they were gone and none could be found in the valley." This observation was made in a mountain valley "above the limit of beet raising and no doubt above the limit of their breeding range," and was located in the approach to a mountain pass leading over to the southern desert.

In California the writer saw apparently the same behavior at 130 feet below sea level in the Imperial Valley and frequently in the beet fields and also on the plains of the San Joaquin Valley. The behavior is associated with mating and was first studied at Heber in the Imperial Valley on June $3-9,1918$, where an enormous congregation of nymphs and adults had occurred on the Nettle Leaf Goosefoot (Chenopodium

'Ball, E. D., 1917. Utah Agr. Exp. Sta., Bul, 155, pp. 28-29. 
murale) growing near dried Atriplex elegans. The different phases of the sexual behavior were observed through a reading glass having a diameter of six inches and a long focal distance.

During the week in which the sexual behavior was studied at Heber, the beet leafhoppers began to clean their bodies before sundown between 6.30 and $6.45 \mathrm{p} . \mathrm{m}$. The wings were stroked and occasionally raised with the hind legs, the middle and front legs cleaning the rest of the body. Before sundown 20 adults were collected with a pipette while they were engaged in cleaning movements and of this number 12 were males and 8 were females. Even the nymphs were aroused to activity at sunset and cleaned their bodies.

On June 8, a partial eclipse of the sun caused a drop in the temperature but the cleaning reaction started at $6.30 \mathrm{p.} \mathrm{m}$. Observations at Mount Wilson Observatory showed that the solar eclipse began at 2 minutes after 3 o'clock, and ended at 38 minutes after 5 o'clock. At the turning point, 4.21 o'clock, 74 per cent of the sun's surface was obscured.

After the male has cleaned his body he may rest for a time; he then walks forward a short distance at the same time fluttering his wings; he stops suddenly for an instant and moves forward again in the same manner and so on. During the week, 55 adults showing this behavior were captured with a pipette before sundown and all proved to be males. The males walked about on the stem, leaves and cluster of seeds and when one discovered a female he sidled up to her with wings elevated on one side of the body and endeavored to copulate. If the female is not inclined to mate, she may kick viciously with her hind legs at the male and if he persists in his attentions, she may walk or fly away. The male often takes short flights in seeking his mate. Sometimes a male may force his attention on a nymph and cause the latter to rear up the abdomen and kick with the hind legs or the nymph may walk or hop away.

After sundown on a calm evening, both male and female adults were aroused to an unusual activity and took short flights about the weed. Hundreds of leafhoppers on the wing swarmed about the plants. Many specimens came to rest on my clothes, face, hands and reading glass, but just for a few moments and then they took wing again. Twenty-three beet leafhoppers were taken on my clothes and of this number 18 were males and 5 were females.

After darkness had set in about 9 p. m. a light thrown on the Nettle Leaf Goosefoot with a flash light showed that the hoppers were at rest on the weed. During the nights of June 7-8, 49 specimens at rest were caught and of this number 25 were males and 24 were females.

The cleaning movements and sexual behavior were observed in sugar 
beet fields at Le Grand on July 12, and at Manteca on August 31. At Le Grand the males took short flights from beet to beet or somewhat longer flights from 5-10 feet.

During the last week in October the sexual behavior was observed on the plains adjacent to about 50 square miles of Russian Thistles (Salsola kali var. tenuifolia) interspersed with patches of Fog Weeds (Atriplex expansa) growing in the vicinity of Oro Loma in the San Joaquin Valley. The plains extended about 3 miles to the foothills of the Coast Range and on both, the beet leafhoppers were captured on Red Stem Filaree (Erodium cicutarium) during the daytime. A quarter of an hour before the sun sank behind the mountains, an occasional adult was taken on the wing, but the number of flying specimens gradually increased after sundown $(5.05 \mathrm{p} . \mathrm{m}$.). The bugs did not orient themselves with reference to the light northwest wind but flew about in all directions. A person standing quietly on the plains soon became covered with hoppers but the insects seemed to be extremely restless, pausing for a short time and then taking wing again. The males flitted their wings in walking about but the females remained inactive. At one time 6 males circled around or sidled up to a female. At 5.15 the first pair in coition was taken and mating continued until dark. (See Plate 15.)

The windshield of an automobile attracted hundreds of beet leafhoppers after sundown and resembled the swarming of enormous numbers of insects around an electric arc lamp. An insect-net was moved back and forth in front of the windshield and the following proportion of male and female specimens were taken on the plains near Oro Loma on October 31:

$\begin{array}{ccccc}\text { Light males } & \text { Dark males } & \text { Light females } & \text { Dark females } & \text { Total } \\ 58 & 252 & 0 & 34 & 344 \\ 17 \% & 73 \% & & 10 \% & \end{array}$

Does the sexual behavior occur at sunrise? Observations were made at sunrise during two mornings on the Nettle Leaf Goosefoot at Heber in the Imperial Valley. The mornings were cool and at sunrise the hoppers did not stir. An occasional specimen was noticed cleaning its body between 6-7 a. m. but no sexual activity was observed.

When beet leafhoppers were required from shrubby perennialAtriplex for experimental purposes, advantage was taken of the fact that the adults are aroused to activity at sunset and are taken more abundantly after sundown than during the daytime. One of many tests will be given. Two persons swept Cattle Spinach (Atriplex polycarpa) with an insect-net for an hour during the afternoon and the same shrubs were swept for half an hour after sundown with the following results: 
Cattle Spinach, Four Miles South of Shafter, October 28, 1918

2.40 to $3.40 \mathrm{p}, \mathrm{m}$.

Light males 12

56
Dark males Light females

0

3

Dark females

9

Total

24

5.15 to $5.45 \mathrm{p} . \mathrm{m}$.

4

5

61

126

In all probability, the hoppers remain within the shrubs during the daytime, and come to the outer branches and foliage at sunset.

During the summer a student was employed for a week to capture $E$. tenella on sugar beets and he caught as many leafhoppers after sunset when no heary winds were blowing as he did during the entire day.

\section{Nocturnal Habit}

E. tenella is a nocturnal insect and displays a considerable amount of activity at night. Tanglefoot fly paper was fastened to barren sandy soil and on boards attached about two feet above the ground at 9 p. m. in the vicinity of the Nettle Leaf Goosefoot on which an enormous congregation of nymphs and adults had occurred at Heber in the Imperial Valley. The next morning before daylight adults were found adhering to the fly paper.

The nymphs also move about at night and seek new food plants when the vegetation on which they are feeding becomes dry. Strips of tanglefoot fly paper were fastened to the sand at night midway between a dried patch of Nettle Leaf Goosefoot and a half dozen green plants. The next morning at 4 a. m. 9 nymphs and 5 adults were found on the fly paper.

There is some evidence to show that the nymphs will leave green plants and wander about on the ground at night. Strips of tanglefoot fly paper were fastened to the sand at night on all sides of an isolated Nettle Leaf Goosefoot plant, at a distance of one yard from the terminal end of the branches. The next morning before daylight 12 nymphs and 4 adults were found sticking to the fly paper.

During the night large numbers of nymphs and adults left green Nettle Leaf Goosefoot plants and were found on the sand below the weeds before daylight on the next morning. When tanglefoot fly paper was fastened to the sand directly below the branches at night several hundred nymphs and numerous adults were found the next morning. Nymphs and adults, however, were also abundant on the stems, leaves and cluster of seeds of this weed at 4 a. m. Do the hoppers seek the warmth of the sand during the night? 


\section{Reaction to Heat}

It is a well known fact that the larvæ of certain pests are killed when they come in contact with soil on hot days and hence several trials were made with nymphs of $E$. tenella. In one test 100 nymphs collected on the Nettle Leaf Goosefoot at Heber in the Imperial Valley were dropped on soil in a depression which had been irrigated and baked into a hard crust. When the insects came in contact with the hot ground they hopped about at a lively rate. A large specimen was followed and it soon became evident that the distance of each leap became shorter and shorter. Oftentimes the hopper fell on its back after a jump and experienced difficulty in righting itself. At the end of 20 minutes the creature was lying on its back and made no further effort to move. It had hopped 15 feet from the point of liberation. The experiment was repeated several times and in each case the nymph died. The thermometer registered $110^{\circ} \mathrm{F}$. in the shade.

\section{Phототахіs}

On rare occasions the beet leafhopper is attracted to electric lamps. At Coalinga in the San Joaquin Valley, the adults were taken on a glass show case situated below a 200 watt "Daylight Lamp," on show windows and in bowls enclosing incandescent electric lamps fastened to the ceiling at the entrance of stores. The following figures give the proportion of sexes:

July $15 / 18$

Aug. $3 / 18$

\begin{tabular}{ccc} 
Males & Females & Total \\
3 & 26 & 29 \\
21 & 113 & 134 \\
\hline 24 & $\frac{139}{163}$ \\
$14 \%$ & $85 \%$ &
\end{tabular}

At Coalinga the adults showed a positive reaction to an auto spot light and left the Fog Weed and congregated on the soil illuminated by the lamp. When the spot light was held a few feet from the hoppers some of the specimens flew to the light. Similar results were obtained near Shafter on July 18.

In the Imperial Valley enormous numbers of Jassids were attracted to electric lamps in cantaloupe packing sheds on calm evenings. A single female beet leafhopper was captured at Heber on June 7, but not another specimen was taken from June 8-15.

\section{Reaction to Shadow}

When a person walked past a Nettle Leaf Goosefoot plant a swarm of adults flew up, some settled on the ground but most of them came to rest upon the weed. Before and after sunrise, however, the hoppers 
did not respond, probably due to the lower temperatures. When a person stood perfectly quiet near a plant and a shadow was thrown on the weed, some of the leafhoppers immediately flew about. When an insect-net was moved about but without casting a shadow upon the plant, the bugs did not fly from the weed. Evidently the insects do not respond to a moving object but a shadow arouses some of them to activity.

Chatrman H. J. Quayle: I see Prof. Doane is here now. We will listen to his paper on "Weevils in Australian Wheat in California."

\section{WEEVILS IN AUSTRALIAN WHEAT IN CALIFORNIA}

By R. W. Dosne, Stanford Universily, California. Collaborator, Bureau of Entomology, U. S. Department Agriculture

The great demand for vessels of all kinds that came with the beginning of the late war soon interrupted the normal movement of foodstuffs in all parts of the world. In a very short time the serious results of this restricted movement began to be apparent in many quarters. Vast quantities of food that were badly needed elsewhere began to accumulate in certain centers where no provision was ever made to handle it in such unusual amounts.

One of the most serious situations brought about by this condition was the accumulation of millions of bushels of wheat in the Australian and New Zealand seaports, where most of it had to lay for many months; some for three or four years, awaiting shipment. It was inevitable that the weevils and other insects should take advantage of such an opportunity to wax fat and multiply.

I have not seen any account of the work that has been done in Australia in the efforts to control the weevils there, but I have had an opportunity to inspect much of the wheat that has come into San Francisco and Los Angeles from Australia, and to see the way in which the mills here handle the infested grain.

The wheat was imported by the Grain Corporation of the United States Food Commission, and sold to the mills that seemed to need it most. Most of it went to mills in San Francisco and Vallejo, but some went to Stockton and some to Los Angeles and vicinity, and smaller amounts to Oregon and Arizona. All of the mills receiving this wheat were working on government contracts, furnishing the government a certain amount of flour or other products. The Grain Corporation assumed no control over the wheat after it was taken from the docks by the mills. 